\title{
Influencia de diferentes condiciones de curado en la estructura porosa y en las propiedades a edades tempranas de morteros que contienen ceniza volante y escoria de alto horno
}

\section{Influence of different curing conditions on the pore structure and the early age properties of mortars with fly ash and blast-furnace slag}

\author{
J. M. Ortega(*), I. Sánchez ${ }^{(*)}, \underline{\text { M. Á. Climent }}{ }^{(*)}$
}

Recepción/Received: 25-X-11

Aceptación/Accepted: 23-I-12

Publicado online/Online publishing: 01-III-12

\section{RESUMEN}

En este trabajo se ha estudiado la evolución de la microestructura, propiedades de durabilidad y resistencias mecánicas de morteros preparados con cementos comerciales, que contienen ceniza volante (entre un $21 \%$ y un $35 \%$ ) y escoria de alto horno (entre un $66 \%$ y un $80 \%$ ), expuestos a tres ambientes, un ambiente óptimo de laboratorio, y dos ambientes representativos del clima Atlántico y Mediterráneo respectivamente. Como referencia de comportamiento, también se ensayaron morteros de cemento Portland. La microestructura se caracterizó mediante porosimetría de intrusión de mercurio. En lo referente a la durabilidad, se estudiaron los coeficientes de absorción capilar y de migración de cloruros en estado no estacionario. También se determinó la resistencia a compresión de los morteros. Los ensayos se realizaron a 7, 28 y 90 días. La principal conclusión alcanzada es que los cementos con cenizas y escorias expuestos a condiciones ambientales representativas de los climas Atlántico y Mediterráneo, pueden desarrollar unas propiedades en servicio adecuadas al cabo de tres meses.

Palabras clave: escoria de alto horno; ceniza volante; ambiente de endurecimiento; microestructura; durabilidad.

\begin{abstract}
In this work, the evolution of the microstructure, durability properties and mechanical strength of mortars made with commercial cements, which contain fly ash (between $21 \%$ and $35 \%$ ) and ground granulated blast-furnace slag (between 66\% and 80\%), were studied. These mortars were exposed to three different environments during their hardening, an optimum laboratory condition, and two environments representing a mild Atlantic climate and a Mediterranean climate, respectively. As a reference, ordinary Portland cement mortars were also tested. The microstructure was characterized using mercury intrusion porosimetry. Regarding durability, the capillary suction coefficient and non-steady-state chloride migration coefficient were determined. Compressive strength was studied too. The tests were performed at 7, 28 and 90 days. The main conclusion of this work is that cements with slag and fly ash hardened under environmental conditions of Atlantic and Mediterranean climates, can develop good service properties after three months of hardening.
\end{abstract}

Keywords: ground granulated blast-furnace slag; fly ash; hardening environment; microstructure; durability.

(*) Universidad de Alicante (Alicante/Alacant, España). 


\section{INTRODUCCIÓN}

En los últimos años, cada vez es más frecuente el uso de adiciones activas en el hormigón. Su uso conlleva importantes ventajas desde el punto de vista medioambiental, ya que permite reducir las emisiones de $\mathrm{CO}_{2}$ y el consumo de energía, al ser necesaria una menor cantidad de clínker en la fabricación del cemento, y además pone en valor un residuo, minimizando de este modo el problema que traería consigo su almacenaje. Entre las diferentes adiciones activas existentes, la ceniza volante y la escoria de alto horno, y sus efectos en las propiedades de los materiales cementicios constituyen en la actualidad un importante campo de investigación $(1,2)$.

Numerosos trabajos $(1,3,4)$ han demostrado que, expuestos a condiciones óptimas de laboratorio, los cementos que incorporan estas adiciones presentan un buen comportamiento en lo que a las propiedades en servicio se refiere, incluso mejor que el observado para el cemento Portland $(5,6)$. La escoria de alto horno posee propiedades hidráulicas, por lo que empezaría a reaccionar desde el momento del amasado, mientras que la ceniza volante posee propiedades puzolánicas, así que sus partículas necesitan la presencia de portlandita, formada en la hidratación del clínker, para comenzar a reaccionar (7). El buen comportamiento de los cementos que incorporan estas adiciones, se debe a que los productos formados en las reacciones anteriores, traen consigo un mayor refinamiento de la microestructura de morteros y hormigones $(1,5,8)$. Las propiedades de durabilidad de los materiales cementicios están directamente relacionadas con su microestructura (9), por lo que la adición de escoria de alto horno y ceniza volante reduce la permeabilidad del hormigón y mejora su resistencia al ingreso de agentes agresivos $(10,11)$.

No obstante, el fraguado y el endurecimiento del hormigón que forma parte de las estructuras reales se produce en condiciones ambientales diferentes de las óptimas de laboratorio, en las que habitualmente se estudian los materiales. Además, estas condiciones también pueden variar en función de la localización geográfica de la estructura u obra en concreto. La temperatura y la humedad relativa $(12,13)$ del ambiente pueden afectar al desarrollo de la hidratación de la escoria y a la reacción puzolánica de la ceniza volante. En ese caso, podrían producirse cambios en la microestructura (14) de morteros y hormigones, y como consecuencia, sus propiedades en servicio se podrían ver afectadas (15).

En vista de ello, el objetivo que se plantea para este trabajo es estudiar la evolución de la microestructura, propiedades de durabilidad y resistencia mecánica de morteros preparados con cementos que contienen escoria de alto horno y ceniza volante expuestos a una serie de

\section{INTRODUCTION}

In recent years, the use of active additions in concrete is more and more common. Their use provides important advantages from an environmental point of view, because it allows reducing the $\mathrm{CO}_{2}$ emissions and the energy consumption, due to being necessary a lower quantity of clinker during the cement production. Besides, the use of active additions can put in value waste materials, thus alleviating their storage or disposal problem. Among the different active additions existing, fly ash and blastfurnace slag, and their effects on the properties of the cementitious materials represent nowadays an important research field $(1,2)$.

Many studies $(1,3,4)$ have shown that, exposed to optimum laboratory conditions, the cements which incorporate these additions present a good behaviour with regard to service properties, even better than that observed for Portland cement $(5,6)$. Blast-furnace slag has hydraulic properties, therefore it would start to react since the setting moment, while fly ash has pozzolanic properties, so their particles need the presence of portlandite, produced during clinker hydration, for starting to react (7). The good behaviour of cements which incorporate these additions is due to the products produced during the abovementioned reactions, which bring with them an important refinement of mortars and concretes microstructure $(1,5,8)$. Durability properties of cementitious materials are directly related to their microstructure (9), therefore the addition of blast-furnace slag and fly ash reduces the permeability of concrete and improves their resistance to aggressive agents ingress $(10,11)$.

However, the setting and the hardening of concrete which forms real structures is produced in environmental conditions different from the optimum laboratory ones, where materials are usually studied. Furthermore, these conditions can also change as a function of the geographical location of the particular structure or building work. The environmental temperature and relative humidity $(12,13)$ may influence the development of slag hydration and the pozzolanic reaction of fly ash. This can produce changes in mortars and concretes microstructure (14), and as a consequence, their service properties could be affected (15).

In view of that, the objective of this work is to study the evolution of microstructure, durability properties and mechanical strength of mortars prepared with cements which contain blast-furnace slag and fly ash, exposed to various environments representative of different climatic 
ambientes representativos de diferentes condiciones climáticas existentes en la Península Ibérica, en comparación con el comportamiento de morteros de cemento Portland expuestos a las mismas condiciones.

\section{PROGRAMA EXPERIMENTAL}

\subsection{Preparación de muestras y condiciones ambientales}

Los morteros se prepararon con tres cementos comerciales, un cemento Portland, CEM I 42,5 R (a partir de ahora se hará referencia a él como CEM I), un cemento Portland con ceniza volante, CEM II/B-V 42,5 R (CEM II de ahora en adelante), y un cemento con adición de escoria de alto horno, III/B 42,5 L/SR (CEM III de ahora en adelante), designados según la norma UNE-EN 197-1 (16). El porcentaje de sustitución de clínker por ceniza volante en el CEM II estaba comprendido entre un $21 \%$ y un $35 \%$, mientras que el contenido de escoria del CEM III variaba entre un $66 \%$ y un $80 \%$. La relación agua:cemento en todos los morteros ha sido de 0,5. Respecto al árido fino, se empleó arena silícea normalizada según la norma UNE-EN 196-1 (17). La relación árido:cemento fue 3:1 para todas las muestras.

Se prepararon dos tipos de probetas. Por un lado, probetas cilíndricas de $10 \mathrm{~cm}$ de diámetro y $15 \mathrm{~cm}$ de altura, que se utilizaron para la caracterización de la microestructura y de las propiedades de durabilidad. Por otra parte, se elaboraron probetas prismáticas de $4 \mathrm{~cm} \times 4 \mathrm{~cm} \times 16 \mathrm{~cm}$ según lo indicado en la norma UNE-EN 196-1 (17), con el fin de determinar la resistencia a compresión de los morteros. Una vez amasadas, las probetas fueron introducidas en una cámara húmeda ( $20^{\circ} \mathrm{C}$ y $95 \%$ HR) durante 24 horas. A continuación, fueron desmoldadas y las probetas cilíndricas se cortaron en cilindros de $5 \mathrm{~cm}$ de espesor.

Los diferentes ambientes de exposición (temperatura y humedad relativa) se consiguieron mediante contenedores sellados herméticamente que contenían en su interior agua o disoluciones de glicerina, que a su vez estaban guardados en cámaras con temperatura controlada. Las concentraciones adecuadas de las disoluciones de glicerina se seleccionaron en función de la humedad relativa que se quería obtener, de acuerdo con lo indicado en la norma DIN 50008 parte 1 (18). Las probetas fueron introducidas en estos contenedores herméticos, evitando cualquier contacto con las disoluciones. Los ambientes de exposición estudiados fueron tres, según se indica en la Tabla 1. En primer lugar, un ambiente óptimo de laboratorio, que se designó como ambiente $\mathrm{A}$, a $20^{\circ} \mathrm{C}$ y humedad relativa (HR) del $100 \%$, escogido como referencia. El resto de ambientes estudiados eran representativos de diferentes climas existentes en la Península Ibérica (España y Portugal), con temperaturas y HR correspondientes conditions present in the Iberian Peninsula, in comparison to the behaviour of Portland cement mortars exposed to the same conditions.

\section{EXPERIMENTAL SETUP}

\subsection{Sample preparation and environmental conditions}

Mortar samples were prepared using three commercial cements, an ordinary Portland cement (OPC), CEM I 42.5 $R$ (CEM I from now on), a Portland cement with fly ash (content of fly ash from 21 to 35\%), CEM II/B-V $42.5 R$ (CEM II from now on), and a ground granulated blastfurnace slag cement (content of slag between 66-80\% of total binder), III/B 42.5 L/SR (CEM III from now on), according to the standard UNE EN 197-1 (16).The water to cement ratio was 0.5 . The fine aggregate used was siliceous sand according to the Spanish standard UNE EN 196-1 (17). The aggregate to cement ratio was 3:1 for all the mortars.

Two kinds of specimens were prepared. Firstly, cylindrical samples (10 cm diameter and $15 \mathrm{~cm}$ height) were made, which were used for microstructure and durability properties characterization. On the other hand, prismatic samples $(4 \mathrm{~cm} \times 4 \mathrm{~cm} \times 16 \mathrm{~cm}$ ) were prepared according to the standard UNE-EN 196-1 (17). The compressive strength of mortars was determined using these prismatic samples. After setting, the samples were kept in a 95\% $\mathrm{RH}$ chamber and $20^{\circ} \mathrm{C}$ for 24 hours. After that time they were demoulded and the cylindrical samples were cut into cylinders of $5 \mathrm{~cm}$ thick.

The environmental exposure conditions (temperature and relative humidity) were obtained by using hermetically sealed recipients containing water or glycerol solutions, and these containers were placed into different chambers with controlled temperature. The appropriate concentrations of the glycerol solutions were selected in order to achieve the target relative humidity values, according to the standard DIN 50008 part 1 (18). The mortar samples were introduced into the containers, without contact with the solutions. Three different environmental conditions were studied, as has been indicated in Table 1. First, an optimum laboratory condition, called environment $A$, with $20{ }^{\circ} \mathrm{C}$ and $100 \%$ relative humidity $(R H)$, which was included as a reference of behaviour. The other environmental conditions studied were representative of different climates present in the Iberian Peninsula (Spain and Portugal). Their values of temperature and $\mathrm{RH}$ were the annual average values for each climate. Environment $B$ represented the Atlantic 
a sus valores medios anuales. El ambiente B representa al clima Atlántico del norte de la Península Ibérica, con $15^{\circ} \mathrm{C}$ y $85 \% \mathrm{HR}$; el ambiente C, con $20{ }^{\circ} \mathrm{C}$ y $65 \% \mathrm{HR}$, es representativo del clima Mediterráneo del este de la Península Ibérica. Los ensayos se realizaron a las edades de 7, 28 y 90 días. climate, present in the north part of Iberian Peninsula, with $15^{\circ} \mathrm{C}$ and $85 \% \mathrm{RH}$. Environment C (20 ${ }^{\circ} \mathrm{C}$ and $65 \%$ $\mathrm{RH}$ ) was representative of Mediterranean climate, present in the east part of Iberian Peninsula. Finally, the tests were performed at 7, 28 and 90 days of age.

Tabla 1 / Table 1

Características de los ambientes estudiados. Characteristics of environments studied.

\begin{tabular}{|c|c|c|c|}
\hline $\begin{array}{c}\text { Condición de curado / } \\
\text { Curing condition }\end{array}$ & $\begin{array}{c}\text { Temperatura / } \\
\text { Temperature }\end{array}$ & $\begin{array}{c}\text { Humedad relativa / } \\
\text { Relative humidity }\end{array}$ & $\begin{array}{c}\text { Clima representado / } \\
\text { Represented climate }\end{array}$ \\
\hline Ambiente A / Environment A & $20^{\circ} \mathrm{C}$ & $100 \%$ & Ambiente de laboratorio / Laboratory condition \\
\hline Ambiente B / Environment B & $15^{\circ} \mathrm{C}$ & $85 \%$ & Clima Atlántico / Atlantic climate \\
\hline Ambiente C / Environment C & $20^{\circ} \mathrm{C}$ & $65 \%$ & Clima Mediterráneo / Mediterranean climate \\
\hline
\end{tabular}

\subsection{Porosimetría de intrusión de mercurio}

Con el fin de estudiar la microestructura de los morteros, se empleó la técnica de la porosimetría de intrusión de mercurio. Esta técnica ha sido muy utilizada para caracterizar la red porosa de materiales cementicios (19), a pesar de que presenta algunos inconvenientes $(20,21)$. Previamente a ser ensayadas, las muestras se secaron en estufa a $105^{\circ} \mathrm{C}$ durante 24 horas, a pesar de que ello pudiera cambiar el ángulo de contacto entre el mercurio y el cemento (22). El porosímetro empleado fue un Autopore IV 9500, que permite analizar poros desde 0,9 $\mathrm{mm}$ hasta $5 \mathrm{~nm}$ de diámetro. Para cada condición se realizaron dos ensayos. Se analizaron la porosidad total y la distribución de poros por tamaños. El estudio de la distribución de poros por tamaños se realizó considerando los siguientes intervalos: < $10 \mathrm{~nm}, 10-100 \mathrm{~nm}, 100 \mathrm{~nm}-1 \mu \mathrm{m}, 1-10 \mu \mathrm{m}$, $10 \mu \mathrm{m}-0,1 \mathrm{~mm}$ y $>0,1 \mathrm{~mm}$.

\subsection{Ensayo de absorción capilar}

El ensayo de absorción capilar se efectuó según la norma UNE 83.982 (23), que se basa en el método Fagerlund para determinar la capilaridad del hormigón. Se ensayaron probetas cilíndricas de $10 \mathrm{~cm}$ de diámetro y $5 \mathrm{~cm}$ de espesor. Siguiendo las indicaciones de la recomendación Rilem TC 116-PCD (24), se selló la mitad inferior de la superficie lateral de la probeta mediante cinta adhesiva, para asegurar que solamente estaba en contacto con el agua una de las caras basales planas de la probeta.

En la bibliografía se encuentran recomendaciones para el acondicionamiento de las probetas sometidas a ensayos de capilaridad, que consisten en la implementación de un grado de saturación de agua correspondiente al equilibrio con una atmósfera de $75 \%$ de humedad relativa, mediante una fase de secado a $50{ }^{\circ} \mathrm{C}$ y una fase de redistribución de la humedad $(24,25)$. No obstante existen

\subsection{Mercury intrusion porosimetry}

Mercury intrusion porosimetry was used for studying the microstructure of the hardened mortar samples. This is a well-known and very used technique to characterize the porous network of cementitious materials (19), in spite of being reported the main problems associated with its use $(20,21)$. Samples were oven dried for 24 hours at $105^{\circ} \mathrm{C}$ before the test, even though this fact could change the contact angle between mercury and cement (22). The porosimeter employed was an Autopore IV 9500, which allows pore diameter determination in the range from 0.9 $\mathrm{mm}$ to $5 \mathrm{~nm}$ of diameter. Two measurements were made on each condition. The total porosity and the pore size distribution were analysed. The study of pore size distribution of samples was done considering the following diameter ranges: < $10 \mathrm{~nm}, 10-100 \mathrm{~nm}, 100 \mathrm{~nm}-1 \mu \mathrm{m}, 1-10 \mu \mathrm{m}, 10$ $\mu \mathrm{m}-0.1 \mathrm{~mm}$ and $>0.1 \mathrm{~mm}$

\subsection{Capillary absorption test}

The capillary absorption test was performed according to the standard UNE 83.982 (23), which is based on the Fagerlund method for determining the capillarity of concrete. Cylindrical samples of $10 \mathrm{~cm}$ diameter and $5 \mathrm{~cm}$ height were tested. According to the Rilem recommendation TC $116-P C D$ (24), the lateral surface of the samples was sealed using self-adhesive tape. This guarantees that only the base of the samples was in contact with water.

There are recommendations in the literature about the pre-conditioning procedure for samples subjected to capillary tests, which consist to impose a water saturation degree corresponding to the equilibrium with an atmosphere with $75 \%$ of relative humidity. This water saturation degree is reached through a phase of drying at $50^{\circ} \mathrm{C}$ and a phase of humidity redistribution $(24,25)$. However, there 
otras normativas que prescriben el secado completo a $105^{\circ} \mathrm{C}(26)$. Aunque el primer procedimiento entraña menor riesgo de modificaciones microestructurales debido al valor más bajo de la temperatura de secado, su puesta en práctica implicaría tiempos de acondicionamiento bastante prolongados (del orden de un mes mínimo para cada condición ensayada), y, en el caso del presente trabajo, en que se parte de probetas curadas en ambiente no saturado de humedad, la necesidad en muchos casos de una humectación previa para poder comenzar la fase de secado. Por todo ello, teniendo en cuenta la gran cantidad de muestras a ensayar, y la necesidad de que todas las propiedades de transporte se determinasen aproximadamente a los mismos tiempos, se decidió utilizar en el presente trabajo el secado a $105^{\circ} \mathrm{C}$ durante 12 horas, y desde entonces hasta el inicio del ensayo, las probetas fueron mantenidas en contenedores sellados herméticamente con gel de sílice en su interior durante las siguientes 12 horas.

Según la norma UNE 83.982 (23), el coeficiente de absorción capilar se determinó mediante las siguientes expresiones [1]: are other standards which suggest a complete drying at $105^{\circ} \mathrm{C}$ (26). Although the risk of producing microstructu$\mathrm{ral}$ modifications is less for the first procedure, due to the lower value of drying temperature, its main problem is the inherent very long conditioning time (a month minimum for each condition studied). Besides, in the case of this work, where the majority of the samples were cured in non-saturated environments, it would be also necessary a previous process of saturation, before the drying phase of the samples. For this reason, and due to the big amount of samples tested, and the need of determining the transport properties at the same ages approximately, the selected pre-conditioning procedure in this work was to completely dry the mortar samples for 12 hours at $105^{\circ} \mathrm{C}$ and, since then until the beginning of the test, to keep them in a hermetically sealed container with silica gel during the next 12 hours.

According to the standard UNE 83.982 (23), the capillary suction coefficient was calculated using these expressions [1]:

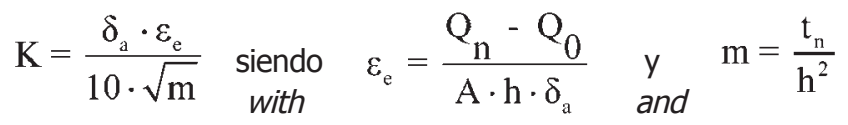

donde: $\mathrm{K}$ es el coeficiente de absorción capilar ( $\mathrm{kg} /$ $\left.\mathrm{m}^{2} \min ^{0,5}\right) . \varepsilon_{\mathrm{e}}$ es la porosidad efectiva. $Q_{n}$ es la masa de la probeta al alcanzar la saturación al final del ensayo $(\mathrm{g})$. $\mathrm{Q}_{0}$ es la masa de la probeta antes de iniciar el ensayo $(\mathrm{g})$. A es el área de la sección de la probeta en contacto con el agua $\left(\mathrm{cm}^{2}\right)$. h es el espesor de la probeta $(\mathrm{cm}) . \delta_{a}$ es la densidad del agua $\left(1 \mathrm{~g} / \mathrm{cm}^{3}\right)$. $\mathrm{m}$ es la resistencia a la penetración del agua por la absorción capilar $\left(\mathrm{min} / \mathrm{cm}^{2}\right)$. $t_{n}$ es el período de tiempo para alcanzar la saturación (minutos).

Para cada tipo de cemento y ambiente se ensayaron tres probetas.

\subsection{Ensayo de migración forzada por campo eléctrico}

El ensayo de migración forzada de cloruros fue realizado según el proceso descrito en la norma NT Build 492 (27), cuyo principal resultado es el coeficiente de migración de cloruros en estado no estacionario, $D_{\text {NTB }} \mathrm{m}^{2} / \mathrm{s}$. Se ensayaron probetas cilíndricas de $10 \mathrm{~cm}$ de diámetro y $5 \mathrm{~cm}$ de espesor. Previamente al ensayo, las probetas fueron saturadas de acuerdo con lo indicado por la norma ASTM C1202-97 (28). La elección de este tipo de ensayo de migración radica en la necesidad de minimizar tanto la duración del ensayo como el tiempo durante el cual las probetas de mortero están en contacto con agua, con el fin de que los posibles cambios en su microestructura y en su where: $K$ is the capillary suction coefficient $\left(\mathrm{kg} / \mathrm{m}^{2} \mathrm{~min}^{0.5}\right)$. $\varepsilon_{\mathrm{e}}$ is the effective porosity. Qn is the weight of the sample at the end of the test $(\mathrm{g}) . Q_{0}$ is the weight of the sample before starting the test $(\mathrm{g}) . A$ is the surface of the sample in contact with water $\left(\mathrm{cm}^{2}\right) . h$ is the thickness of the sample $(\mathrm{cm}) . \delta_{a}$ is the density of water $\left(1 \mathrm{~g} / \mathrm{cm}^{3}\right) . m$ is the resistance to water penetration by capillary suction $\left(\mathrm{min} / \mathrm{cm}^{2}\right) . t_{n}$ is the time necessary to reach the saturation (minutes).

For each cement type and environment, three different samples were tested.

\subsection{Forced migration test}

The forced chloride migration test was performed according to the standard NT Build 492 (27). Its main result is the non-steady-state chloride migration coefficient, $D_{N T B} m^{2} / s$. Cylindrical samples of $10 \mathrm{~cm}$ diameter and $5 \mathrm{~cm}$ height were tested. Before the test, samples were saturated according to the ASTM Standard C1202-97 (28). The choice of this migration test procedure was based on the need to minimize both the testing time and the contact time of the mortar specimens with aqueous solutions, in order to modify as less as possible the microstructure and hydration degree of the mortar samples due to the testing conditions. For each 
grado de hidratación debidos a las condiciones del ensayo sean los mínimos posibles. Para cada tipo de cemento y ambiente se ensayaron tres probetas diferentes.

\subsection{Determinación de la resistencia mecánica}

Las resistencias fueron determinadas según la norma UNE-EN 196-1 (17). Se ensayaron probetas de $4 \mathrm{~cm} \times 4$ $\mathrm{cm} \times 16 \mathrm{~cm}$, de las que se obtuvo su resistencia a compresión. Para cada tipo de cemento y ambiente se ensayaron tres probetas diferentes.

\section{RESULTADOS Y DISCUSIÓN}

\subsection{Porosimetría de intrusión de mercurio}

Los cambios en la porosidad total de las probetas expuestas al ambiente A se presentan en la Figura 1. A partir de 28 días, los morteros de CEM III mostraron la menor porosidad total de todos los cementos estudiados. Para los morteros de CEM III, el principal descenso de la porosidad se produjo entre 7 y 28 días, mientras que en los morteros de CEM II se observó una ligera disminución de este parámetro entre 28 y 90 días. Por el contrario para el CEM I, la porosidad total en el ambiente $A$ mostró valores bajos iniciales, pero se mantuvo constante en el tiempo. En general, la porosidad total fue muy similar para los morteros de CEM I y CEM II endurecidos en este ambiente.

Los cambios en la distribución de poros observados en el ambiente A se representan en la Figura 2. En primer lugar, es de destacar que en los cementos con adiciones la microestructura era más refinada, como mostraba la mayor proporción de poros de menores tamaños (intervalo $<10 \mathrm{~nm}$ ), más notorio a las edades de 28 y 90 días y para morteros de CEM III. El hecho de que la incorporación de escoria y ceniza causa un mayor refinamiento de la estructura de poros es muy conocido $(1,8,29)$. Esto se debe a que las reacciones de la escoria y la ceniza forman fases CSH adicionales $(10,30)$, lo que trae consigo que la red de poros sea cada vez más compacta. Además, en el ambiente A estas reacciones, junto con la hidratación del clínker, se verían favorecidas por la elevada humedad relativa (31), lo que se manifiesta en el mayor refinamiento de la red de poros con la edad en los tres tipos de mortero.

Por otro lado, el hecho de que a 7 días la red porosa no fuese tan refinada en los morteros de CEM II como en los de CEM III, pero que a 90 días sea similar en ambos, estaría relacionado con que la ceniza volante tiene propiedades puzolánicas y no hidráulicas, como la escoria de alto horno. En ese caso, es necesaria la presencia de portlandita que se forma en la hidratación del clínker para el inicio de la reacción puzolánica $(1,2,6,7)$. Por lo tanto, siempre habrá un desfase entre las reacciones de cement type and environment, three different samples were tested.

\subsection{Mechanical strength determination}

The strength was determined according to the standard UNE-EN 196-1 (17). Samples of $4 \mathrm{~cm} \times 4 \mathrm{~cm} \times 16 \mathrm{~cm}$ were tested, and their compressive strength was obtained. For each cement type and environment, three different samples were tested.

\section{RESULTS AND DISCUSSION}

\subsection{Mercury intrusion porosimetry}

The changes of total porosity for samples exposed to environment $A$ are presented in Figure 1. Since 28 days, CEM III mortars showed the lowest total porosity of all cements studied. For CEM III samples, the main decrease of porosity was produced between 7 and 28 days, while for CEM II mortars, it was observed a small decrease of this parameter between 28 and 90 days. On the other hand, in the case of CEM I, the total porosity showed low initial values for environment $A$, although it kept constant with time. In general, the total porosity was very similar for CEM I and CEM II mortars hardened under this environment.

The changes of pore size distribution observed for environment $A$ are represented in Figure 2. First, it is important to emphasize the fact that the microstructure was more refined for cements with additions, as shown by the higher proportion of smaller pores (pore diameter range $<10 \mathrm{~nm}$ ). This is more evident at the ages of 28 and 90 days and for CEM III mortars. The higher refinement of porous structure produced by the incorporation of fly ash and slag is well-known $(1,8,29)$. This is a consequence of the formation of additional CSH phases $(10,30)$ during the reactions of slag and fly ash, which produces a more compact porous network. Moreover, for environment $A$, the high relative humidity would favour the clinker hydration and the development of the pozzolanic reactions (31), as revealed by the progressive microstructure refinement with age observed for the three types of mortars studied.

On the other hand, the fact that the microstructure of CEM II mortars at 7 days of age was less refined in comparison to CEM III ones, and that it was similar for both types of mortars at 90 days, could be related to the fact that fly ash has pozzolanic properties, but not hydraulic properties, quite the opposite than slag. In that case, it is necessary the presence of portlandite, which is produced in clinker hydration, to initiate the pozzolanic reaction $(1,2,6,7)$. Then, it will always be a time lag between the hydration 
hidratación y puzolánica, y por eso los efectos de estas últimas en la estructura porosa se hacen más notables a edades mayores.

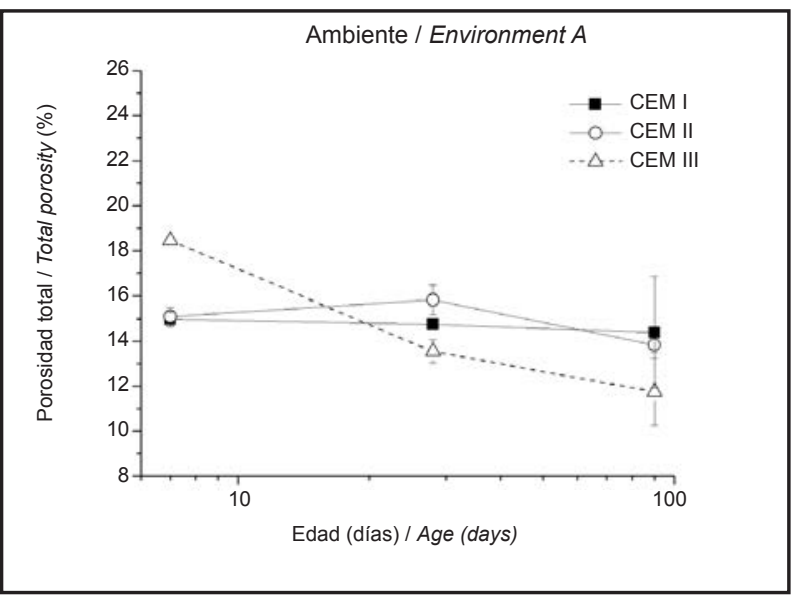

Figura 1. Resultados de porosidad total en los morteros endurecidos en el ambiente $A$, según el tipo de cemento. Cada punto representa el valor medio de las probetas ensayadas. Las barras de error verticales muestran la desviación estándar. En el resto de figuras en que aparecen, los puntos y las barras de error tienen el mismo significado que en esta Figura 1.

Figure 1. Total porosity results for mortars exposed to environment $A$, depending on cement type. Each point represents the mean value of the samples tested. The vertical error bars represent the standard deviation. For the rest of figures, the points and error bars have the same meaning than for this Figure 1.

La variación de la porosidad total con la edad en los morteros endurecidos en el ambiente $B$ se representa en la Figura 3. Esta porosidad se mantuvo constante o disminuyó ligeramente con el tiempo en los tres tipos de morteros estudiados. Además, este parámetro presentó valores similares para todos ellos en la mayoría de edades, aunque es algo mayor en los morteros de CEM II. Si se comparan esos resultados con los obtenidos para el ambiente $A$, los valores de porosidad total eran mayores en el ambiente $B$, sobre todo en el caso de los morteros de CEM III. Por otro lado, los cambios con el tiempo en la distribución de poros por tamaños en los morteros expuestos al ambiente $B$ se muestran en la Figura 4. En los morteros de CEM I, se produjo un refinamiento progresivo de la microestructura con la edad, y al cabo de 90 días de endurecimiento la distribución de poros por tamaños era menos refinada que la observada en el ambiente A. Para el CEM II, la red porosa evolucionó poco con el tiempo y al cabo de 90 días ésta era menos refinada en comparación con el ambiente A, destacando el mayor volumen de poros de tamaños comprendidos entre $100 \mathrm{~nm}$ y $1 \mu \mathrm{m}$ y el menor volumen de poros inferiores a $100 \mathrm{~nm}$. En el caso del CEM III, a las edades de 28 y 90 días, destacó la baja proporción de poros de diámetros menores a $100 \mathrm{~nm}$ con respecto al ambiente $\mathrm{A}$. and the pozzolanic reactions, thus leading to a delay of the effects of the pozzolanic reactions on the porous network, whose changes can be only appreciated at later ages.

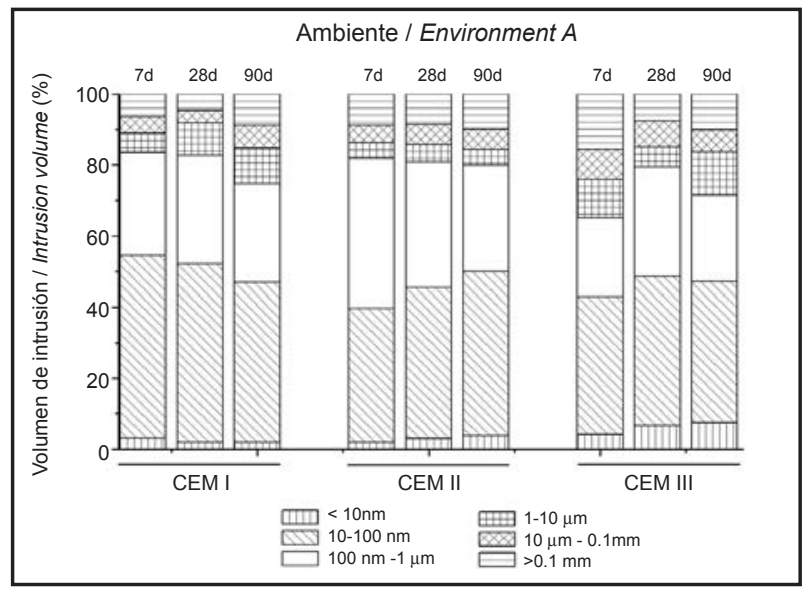

Figura 2. Distribución de poros por tamaños de los morteros expuestos al ambiente $A$.

Figure 2. Pore size distribution for mortars exposed to environment $A$.

The evolution with age of total porosity for mortars hardened under environment $B$ is represented in Figure 3. This porosity kept constant or hardly decreased with time for the three types of mortar studied. Furthermore, this parameter showed similar values for all of them at the majority of the ages, despite of being slightly higher for CEM II mortars. If these results are compared to those obtained for environment $A$, the values of total porosity were higher for environment B, mainly in the case of CEM III. The changes with time of pore size distribution for mortars exposed to environment $B$ are shown in Figure 4. For CEM I mortars, a progressive microstructure refinement was produced with age, and after 90 hardening days their pore size distribution was less refined than that observed for environment A. For CEM II, the porous network hardly developed with age and at 90 days, it was less refined in comparison to environment $A$, with higher volume of pores with diameters between $100 \mathrm{~nm}$ and $1 \mu \mathrm{m}$ and lower volume of pores smaller than $100 \mathrm{~nm}$. In the case of CEM III, at the ages of 28 and 90 days, it was remarkable the low proportion of pores with diameters smaller than 100 $\mathrm{nm}$ in comparison to environment $A$. 
Los resultados parecen indicar que el ambiente B (temperatura más baja y humedad relativa elevada), afectaría en mayor medida a la microestructura de los morteros de CEM II y CEM III. En el caso del CEM II, el hecho de que la porosidad total se mantuviese prácticamente constante y que la distribución de poros por tamaños variara poco entre 28 y 90 días, podría estar relacionado con la menor temperatura del ambiente. Una temperatura baja conllevaría que las reacciones de hidratación del clínker se desarrollasen de forma más lenta (32), lo que produciría un inicio más tardío de la reacción puzolánica de la ceniza volante. Concretamente, los escasos cambios hasta 90 días en su distribución de poros por tamaños, y el menor refinamiento de su red porosa en comparación con el ambiente $A$, sugerirían que a esa edad el avance de la reacción puzolánica fuese muy bajo. El menor refinamiento de la estructura de poros de los morteros de CEM I observada a 90 días en el ambiente $B$, en comparación con el ambiente $\mathrm{A}$, podría ser indicativo de la posible ralentización de la hidratación del clínker a baja temperatura. En lo referente al CEM III, la mayor porosidad total y el menor refinamiento de la microestructura que se observó en el ambiente $B$ con respecto al ambiente $A$, nuevamente estarían en relación con la menor temperatura presente en el ambiente. Es bien conocido que la hidratación de la escoria de alto horno es muy sensible a la temperatura (33), por lo que los cambios en la microestructura en el ambiente $\mathrm{B}$ podrían deberse a la menor temperatura.

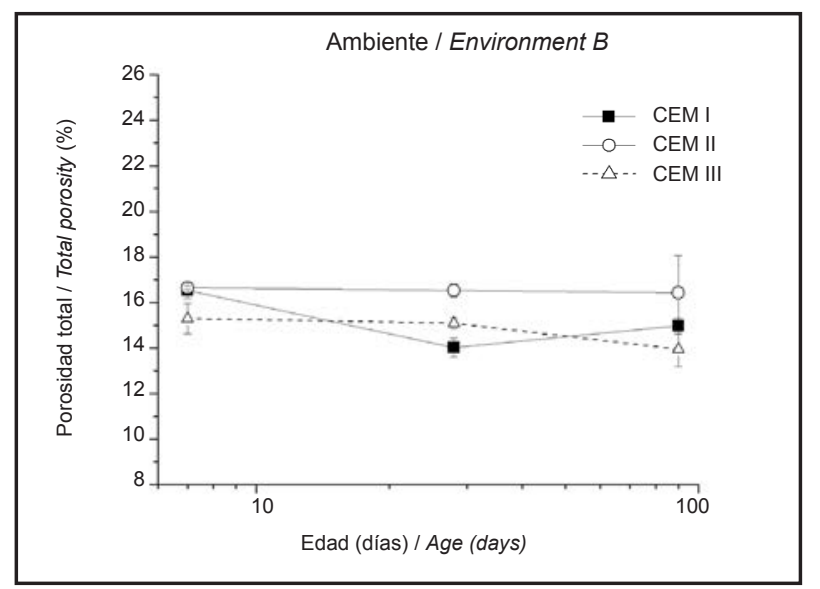

Figura 3. Evolución de la porosidad total en los morteros expuestos al ambiente $\mathrm{B}$.

Figure 3. Evolution of total porosity for mortars exposed to environment $B$.

Los cambios con el tiempo que experimenta la porosidad total en los morteros expuestos al ambiente $C$ se representan en la Figura 5. Entre 7 y 28 días, esta porosidad era prácticamente igual y permaneció sin cambio para los tres tipos de morteros estudiados. A partir de entonces, este parámetro disminuyó en todas las probetas y los morteros de CEM III presentaron la porosidad total más baja, seguidos por los de CEM I, la porosidad total más
The results seem to indicate that environment $B$ (lower temperature than environment $A$ and high relative humidity) would mainly affect the microstructure of CEM II and CEM III mortars. For CEM II, the fact that total porosity kept practically constant and the pore size distribution hardly changed between 28 and 90 days, could be related to the lower environment temperature. A low temperature would produce a slower development of clinker hydration (32), which would also produce a late beginning of the pozzolanic reaction of fly ash. To be precise, the little changes until 90 days observed for their pore size distribution, and the lower microstructure refinement in comparison to environment $A$, would suggest that the degree of pozzolanic reaction development at those ages was very low. The low pore structure refinement observed for CEM I mortars hardened under environment $B$, in comparison to environment $A$, could be indicative of the possible slowing down of clinker hydration at low temperature. Regarding CEM III, the higher total porosity and the lower refinement of microstructure observed for environment $B$ respect to environment $A$, would be related again to the lower temperature of environment $B$. It is well known that the hydration of blast-furnace slag is very sensitive to temperature (33), so the changes in the microstructure for environment $B$ could be due to the lower temperature.

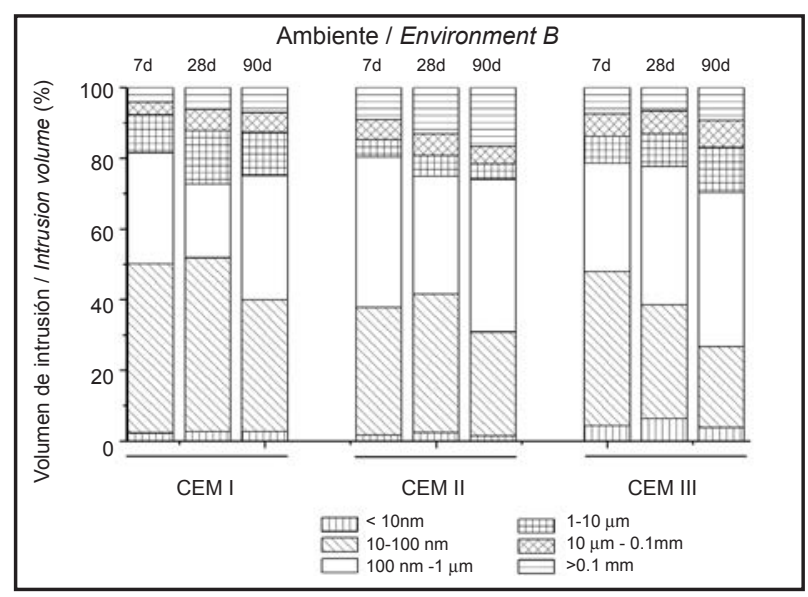

Figura 4. Distribución de poros por tamaños de los morteros expuestos al ambiente $\mathrm{B}$.

Figure 4. Pore size distribution for mortars exposed to environment $B$.

The changes with time of total porosity for mortars exposed to environment $C$ are represented in Figure 5. Between 7 and 28 days, this porosity was practically the same and it kept without changes for the three types of mortars studied. Since then, this parameter decreased for all the samples and CEM III mortars showed the lowest total porosity, followed by CEM I ones, and the highest total porosity was observed for CEM II mortars. The 
alta correspondió a los morteros de CEM II. La evolución de la distribución de poros por tamaños en los morteros endurecidos en el ambiente $C$ se muestra en la Figura 6. Si se comparan estos resultados con los obtenidos para el ambiente $\mathrm{A}$, la red porosa a 90 días era menos refinada en el ambiente $\mathrm{C}$, especialmente para los morteros con adiciones. Por otro lado, si se comparan los resultados de los ambientes B y C, la microestructura de los morteros estudiados no presenta grandes diferencias entre ambos ambientes al cabo de 90 días.



Figura 5. Variación de la porosidad total en los morteros endurecidos en el ambiente $\mathrm{C}$.

Figure 5. Total porosity changes for mortars hardened under environment $C$.

El descenso más tardío de la porosidad total podría estar relacionado con la humedad relativa más baja de este ambiente, ya que al haber menos agua disponible en el ambiente para el desarrollo de las reacciones de hidratación del clínker y escoria, éstas se producirían más lentamente (31). El menor descenso de la porosidad total entre 28 y 90 días que mostraron los morteros de CEM II, así como el menor grado de refinamiento de su microestructura en comparación con los de CEM I, puede estar relacionado nuevamente con el retraso en el inicio de la reacción puzolánica de la ceniza (7), cuyo grado de desarrollo parece ser muy escaso después de 90 días de exposición al ambiente $\mathrm{C}$.

\subsection{Absorción capilar}

La absorción capilar es una de las principales vías de entrada de agentes agresivos en las estructuras de hormigón. Por ello resulta de gran interés analizar cómo influyen las condiciones ambientales en las que se produce el endurecimiento en el coeficiente de absorción capilar K, según el tipo de cemento empleado. La Figura 7 representa los resultados del coeficiente $K$ en los morteros expuestos al ambiente $\mathrm{A}$. El coeficiente $\mathrm{K}$ del CEM I se mantuvo prácticamente constante entre 7 y 90 días. Para los morteros de CEM II, este coeficiente mostró los evolutions of pore size distribution for mortars hardened under environment $C$ are shown in Figure 6. If these results are compared to those obtained for environment $A$, the porous structure was less refined at 90 days for environment $C$, especially for mortars with additions. On the other hand, if we compare the results for environments $B$ and $C$, the microstructure of the studied mortars did not present big differences between both environments at 90 days.

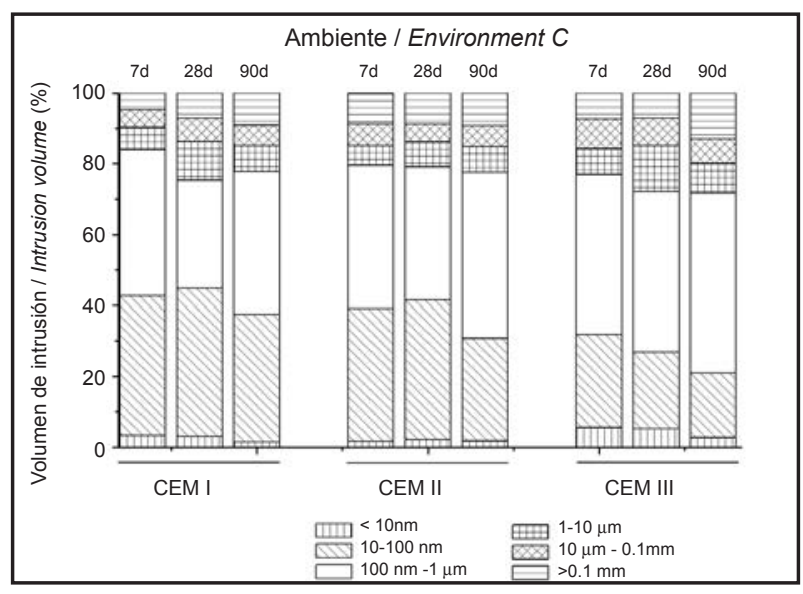

Figura 6. Distribución de poros por tamaños de los morteros endurecidos en el ambiente $\mathrm{C}$.

Figure 6. Pore size distribution for mortars hardened under environment $C$.

The later decrease of total porosity could be related to the lower relative humidity of this environment, because if there is less water available in the environment for the development of hydration reactions of clinker and slag, these would be produced more slowly (31). The lower decrease of total porosity between 28 and 90 days for CEM II mortars, and the lower refinement degree of their microstructure in comparison to CEM I ones, could be related again to the delay of the beginning of fly ash pozzolanic reaction (7), whose development degree seems to be very low after 90 days of exposure to environment $C$.

\subsection{Capillary absorption tests}

The capillary absorption is one of the most important ways of aggressive ingress in concrete structures. For these reason, it is very interesting to analyze the influence of the hardening environment on the capillary suction coefficient $K$, depending on the type of cement employed. Figure 7 represents the results of coefficient $K$ for mortars exposed to environment $A$. The coefficient $K$ for CEM I kept practically constant between 7 and 90 days. For CEM II mortars, this coefficient showed the highest values of the three cements studied at 7 and 28 days, although it 
mayores valores de los tres cementos estudiados a 7 y 28 días, aunque descendió de manera considerable a 90 días. El coeficiente $\mathrm{K}$ del CEM III mostró valores bajos a todas las edades en comparación con el resto de cementos, descendiendo ligeramente entre 28 y 90 días. A 90 días $\mathrm{K}$ era muy similar en los morteros de CEM II y CEM III, y menor que para el CEM I.

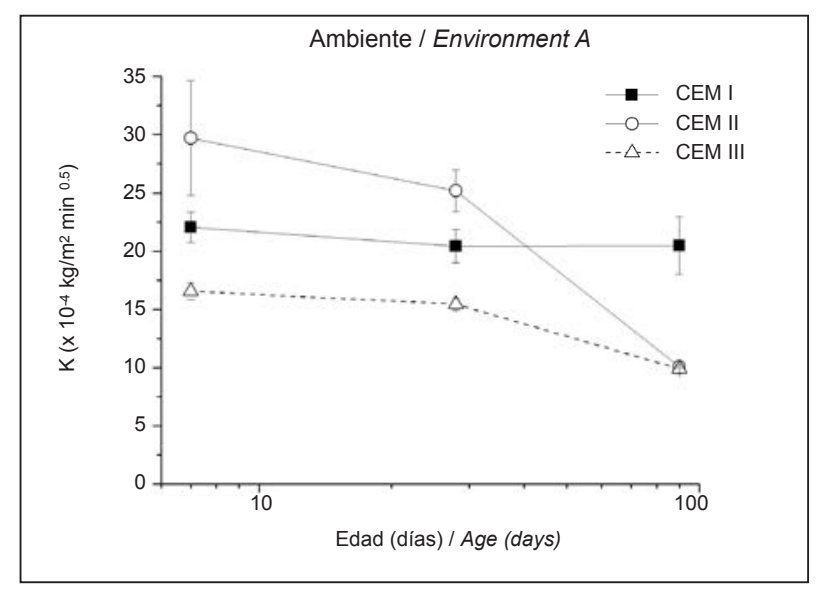

Figura 7. Evolución del coeficiente de absorción capilar (K) en los morteros expuestos al ambiente $A$, según el tipo de cemento empleado.

Figure 7. Evolution of capillary suction coefficient $(K)$ for mortars exposed to environment $A$, depending on the cement type employed.

La variación con la edad del coeficiente $\mathrm{K}$ en los morteros endurecidos en el ambiente $B$ se muestra en la Figura 8. El coeficiente $\mathrm{K}$ presentó escasos cambios entre 7 y 90 días para los morteros de CEM I. Para el CEM II, K disminuyó entre 28 y 90 días, aunque a todas las edades sus valores eran los más elevados de todos los cementos analizados. En los morteros de CEM III, K seguía una tendencia muy similar a la descrita para el CEM I, pero sus valores eran algo menores. Si se comparan los resultados de los ambientes $A$ y $B$, todos los morteros mostraron coeficientes $K$ más elevados en el ambiente $B$, salvo los de CEM I para el que los valores eran similares en ambos ambientes. Los resultados para el ambiente $C$ se representan en la Figura 9. Entre 7 y 28 días, $\mathrm{K}$ presentaba valores muy similares para los tres cementos estudiados, superiores a los observados para cada uno de ellos en los ambientes A y B; a partir de 28 días, $\mathrm{K}$ mostró poca variación para el CEM II, mientras que disminuyó de forma considerable para el CEM I y CEM III.

Los resultados del coeficiente $\mathrm{K}$ coinciden en su mayoría con los de porosidad total ya descritos, por lo que los argumentos expuestos durante su discusión también serían válidos para el coeficiente $\mathrm{K}$. decreased considerably at 90 days. The coefficient $K$ for CEM III showed low values at all ages in comparison to the rest of cements, and it slightly decreased between 28 and 90 days. At 90 days $K$ was very similar for CEM II and CEM III mortars, and lower than for CEM I ones.



Figura 8. Cambios con el tiempo del coeficiente de absorción capilar en los morteros expuestos al ambiente B.

Figure 8. Changes with time of capillary suction coefficient for mortars exposed to environment $B$.

The evolution with age of $K$ coefficient for mortars hardened under environment $B$ is shown in Figure 8. The $K$ coefficient hardly changed between 7 and 90 days for CEM I mortars. For CEM II, $K$ decreased between 28 and 90 days, although at all ages their values were the highest of all cements analyzed. For CEM III mortars, $K$ showed a very similar tendency to that described for CEM I, but their values were slightly lower. If we compare the results for environments $A$ and $B$, all mortars showed higher coefficients $K$ for environment $B$, except CEM I ones, whose values were similar for both environments. The results for environment $C$ are depicted in Figure 9. Between 7 and 28 days, $K$ presented very similar values for the three cements studied, higher than those observed for each one for environments $A$ and $B$; since 28 days, $K$ showed little variation for CEM II, while it decreased considerably for CEM I and CEM III.

Most $K$ coefficient results are in accordance with the total porosity ones previously described. Then, the arguments exposed during the discussion of total porosity results would be also valid for the $K$ coefficient. 


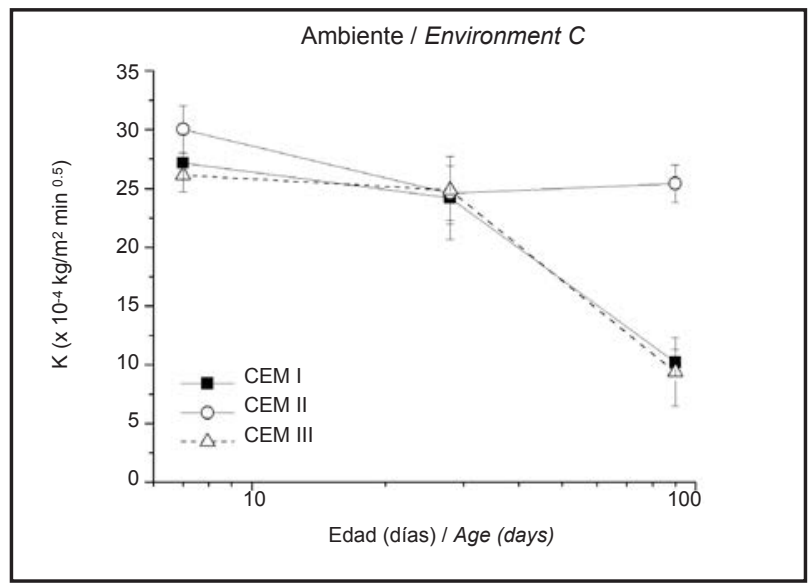

Figura 9. Resultados del coeficiente de absorción capilar en las probetas endurecidas en el ambiente C. Figure 9. Results of capillary suction coefficient for samples hardened under environment $C$.

\subsection{Migración forzada de cloruros}

El estudio de este parámetro resulta de gran interés, ya que el ingreso de cloruros es uno de los factores que puede producir la corrosión de las barras de acero embebidas en el hormigón, especialmente en estructuras situadas en ambiente marítimo. Los resultados del coeficiente de migración en las probetas expuestas al ambiente A se representan en la Figura 10. Los morteros de CEM III fueron los que menor coeficiente de migración presentaron a todas las edades. El coeficiente disminuía de forma importante con el tiempo para las probetas de CEM II, a pesar de presentar un valor elevado a 7 días. Para los morteros de CEM I, este coeficiente también disminuía con el tiempo, aunque a 90 días sus valores eran los más elevados de los tres cementos estudiados. A grandes rasgos, estos resultados del ambiente A son muy similares a los anteriormente discutidos, por lo que los argumentos ya expuestos son válidos también para el coeficiente de migración.

La evolución del coeficiente de migración en los morteros almacenados en las condiciones del ambiente $B$ se representa en la Figura 11. Entre 7 y 90 días, los menores coeficientes de migración correspondieron al CEM III. En el caso del CEM II, este coeficiente disminuía con la edad, pero en menor medida con respecto al ambiente A. Para el CEM I, los cambios con el tiempo del coeficiente de migración fueron escasos, ya que sus valores a 7 y 90 días eran parecidos. Estos resultados tienen similitudes con los mostrados anteriormente para el ambiente $B$, aunque es de destacar que en lo referente al coeficiente de migración, el CEM III presentaría una mayor mejora de comportamiento respecto al CEM I que la observada para el coeficiente de absorción capilar. Por lo que respecta al ambiente $\mathrm{C}$, en la Figura 12 se muestran los resultados del coeficiente de migración, las tendencias son muy similares a las observadas en el ambiente B. Cabe destacar que a 90 días, los coeficientes de los morteros de CEM

\subsection{Forced chloride migration tests}

The study of this parameter is very interesting, because the chloride ingress is one of the factors which can produce steel corrosion of the bars embedded in concrete, especially in the case of structures placed in a maritime environment. The results of the migration coefficient for samples exposed to environment $A$ are depicted in Figure 10. CEM III mortars showed the lowest migration coefficient at all ages. The coefficient decreased considerably with time for CEM II mortars, despite of presenting a high value at 7 days. For CEM I mortars, this coefficient also decreased with age, although at 90 days their values were the highest of the three cements studied. In general, these results for environment $A$ are very similar to those previously discussed, for this reason the arguments already exposed are valid for the migration coefficient too.

The evolution of the migration coefficient values for mortars stored under conditions of environment $B$ is represented in Figure 11. Between 7 and 90 days, the lowest migration coefficients were observed for CEM III. In the case of CEM II, this coefficient decreased with age, but in a lower degree respect to environment $A$. For CEM I, the migration coefficient scarcely changed with time, because their values at 7 and 90 days were similar. These results show coincidences with the results previously shown for environment $B$, although regarding migration coefficient, it is important to emphasize that CEM III would present a higher behaviour improvement in comparison to CEM I than that observed for the capiIlary suction coefficient. With regard to environment $C$, Figure 12 shows the results of migration coefficient, and their tendencies are very similar to those observed for environment B. It is important to stress that at 90 days, the migration coefficient values for CEM II and CEM 
II y CEM III eran menores en el ambiente C que en el B, mientras que para los de CEM I ocurría lo contrario.
III mortars were lower for environment $C$ than those corresponding to environment $B$, while for CEM I ones it happened the opposite.



Figura 10. Resultados del coeficiente de migración de cloruros en estado no estacionario en el ambiente A. Figure 10. Results of non-steady-state chloride migration coefficient for environment $A$.

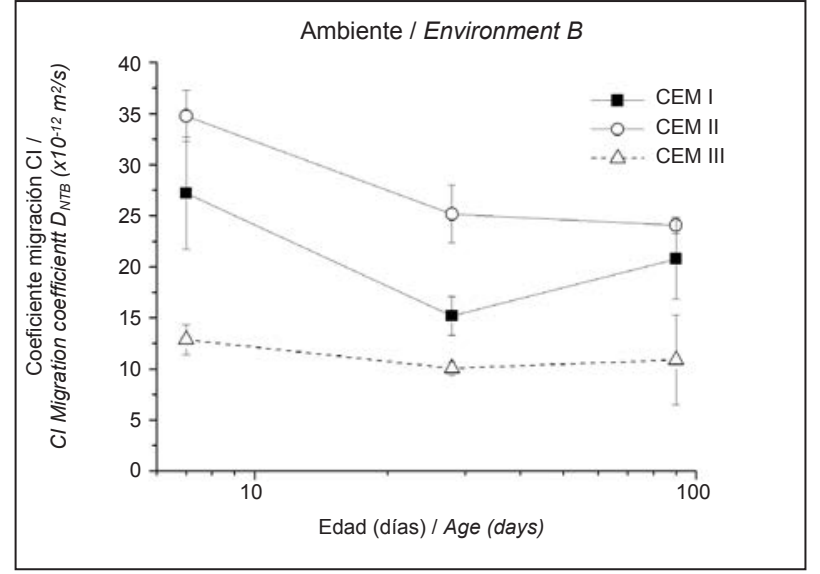

Figura 11. Evolución del coeficiente de migración de cloruros en estado no estacionario para los morteros expuestos al ambiente B.

Figure 11. Evolution of non-steady-state chloride migration coefficient for mortars exposed to environment $B$.

En vista de los resultados del coeficiente de migración de cloruros en estado no estacionario, resulta interesante recalcar que después de 90 días de endurecimiento, en todos los ambientes los morteros con adiciones activas presentaban valores menores a los mostrados por los morteros de cemento Portland, destacando sobre todo los del CEM III. En numerosos estudios $(4,5)$ en condiciones óptimas de laboratorio, se ha demostrado que el empleo de adiciones activas conlleva una considerable mejora en la resistencia al ingreso de cloruros. En el caso particular del CEM III, su mejor comportamiento frente al ingreso de cloruros podría tener relación con la posible formación de sal de Friedel, al tener este cemento más $\mathrm{Al}_{2} \mathrm{O}_{3}$ procedente de la escoria. Del mismo modo, otras investigaciones $(1,34-36)$ han corroborado este buen comportamiento

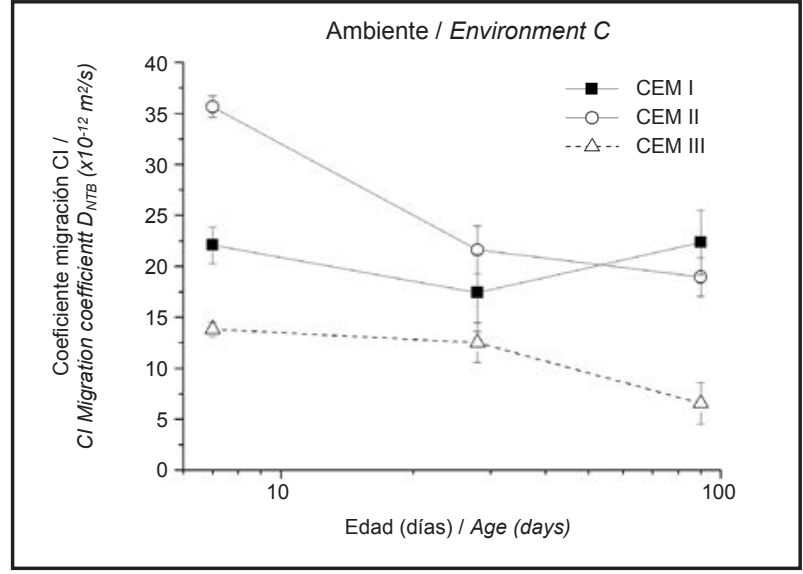

Figura 12. Resultados del coeficiente de migración de cloruros en estado no estacionario en el ambiente $\mathrm{C}$.

Figure 12. Results of non-steady-state chloride migration coefficient for environment $C$.

In view of the results of non-steady-state chloride migration coefficient, it is interesting to emphasize that after 90 hardening days, the mortars with active additions presented lower values than those shown by cement Portland mortars for all environments, especially in the case of CEM III ones. Many studies $(4,5)$ have demonstrated that, for optimum laboratory conditions, the use of active additions produces a substantial improvement in chloride ingress resistance. In the particular case of CEM III, their better behaviour against chloride ingress could be related to the possible formation of Friedel's salt, because this cement has a higher content of $\mathrm{Al}_{2} \mathrm{O}_{3}$ from the slag. Furthermore, other researches $(1,34-36)$ have corroborated this good behaviour for real conditions of some climates throughout the world. The results obtained complement 
en condiciones reales de algunos climas existentes en el mundo. Los resultados obtenidos complementan esos trabajos, ya que también se demuestra que en otros ambientes no óptimos (ambientes B y C), los cementos con ceniza volante y escoria de alto horno tienen un buen comportamiento en lo referente a la resistencia al ingreso de cloruros, en comparación con el cemento Portland, después de un tiempo de maduración suficiente.

\subsection{Propiedades mecánicas}

En las Figuras 13 a 15 aparecen representados los resultados de la resistencia a compresión en los tres ambientes estudiados.

En los tres ambientes, la resistencia a compresión de los morteros aumentó con la edad. En el ambiente A, esta ganancia era mayor en los morteros con adiciones que en los de CEM I; a 90 días los valores eran más elevados que en el resto de ambientes. Esto está en consonancia con los resultados de caracterizar la microestructura y las propiedades relacionadas con la durabilidad, y se explican en base a la elevada humedad relativa presente en el ambiente $A$, que facilitaba el desarrollo de las reacciones de hidratación y puzolánica. Por lo que respecta al ambiente B, destacan las bajas resistencias a compresión a 7 días de los morteros con adiciones; como se explicó previamente, esto podría deberse a la temperatura más baja de este ambiente, que ralentizaría el desarrollo de las reacciones de hidratación y puzolánica. En este ambiente, las resistencias a compresión de los morteros de CEM I eran similares a las del ambiente A. En lo referente al ambiente $C$, las resistencias a 7 días eran más elevadas que en el ambiente $\mathrm{B}$, lo cual se podría justificar en base a la mayor temperatura existente en el primero; no obstante, la ganancia de resistencias se produjo más lentamente que en el resto de ambientes, lo cual podría estar relacionado con la baja humedad relativa del ambiente $\mathrm{C}$, que conllevaría una mayor dificultad para el desarrollo de las reacciones de hidratación y puzolánica.

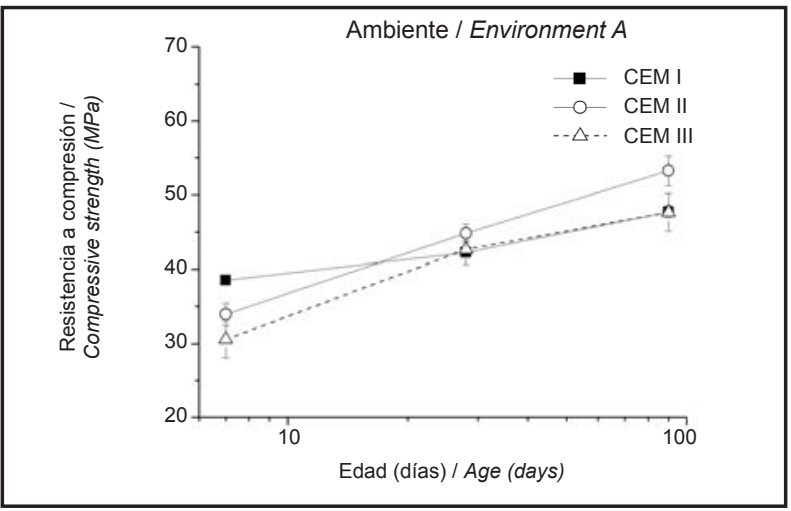

Figura 13. Variación de la resistencia a compresión en los morteros endurecidos en el ambiente $A$. Figure 13. Changes of compressive strength for mortars hardened under environment $A$. those researches, because they also demonstrate that for other non-optimal environments (environments $B$ and $C$ ), cements with fly ash and slag have a good performance regarding chloride ingress resistance, compared to Portland cement, after an enough maturing time.

\subsection{Mechanical properties}

Figures 13 to 15 represent the results of compressive strength for the three environments studied.

For the three environments, the compressive strength of mortars increased with age. For environment $A$, this increase was higher for mortars with additions than for CEM I ones; at 90 days their values were higher than those observed for the rest of environments. This is in accordance with the results of microstructure and durability-related properties characterization, and they can be explained on the basis of the high relative humidity of environment $A$, which facilitated the development of hydration and pozzolanic reactions. With respect to environment $B$, it is remarkable the low compressive strengths at 7 days for mortars with additions; as has been previously explained, this could be due to the lower temperature of this environment, which would slow down the development of hydration and pozzolanic reactions. For this environment, the compressive strengths of CEM I mortars were similar to those observed for environment $A$. Regarding environment $C$, the strengths at 7 days were higher than those observed for environment $B$, which could be explained on the basis of the higher temperature of the first one. Nevertheless, the strength gain was produced more slowly than observed for the rest of environments, which could be related to the low relative humidity in environment $C$. This would produce a larger difficulty to develop the hydration and pozzolanic reactions.

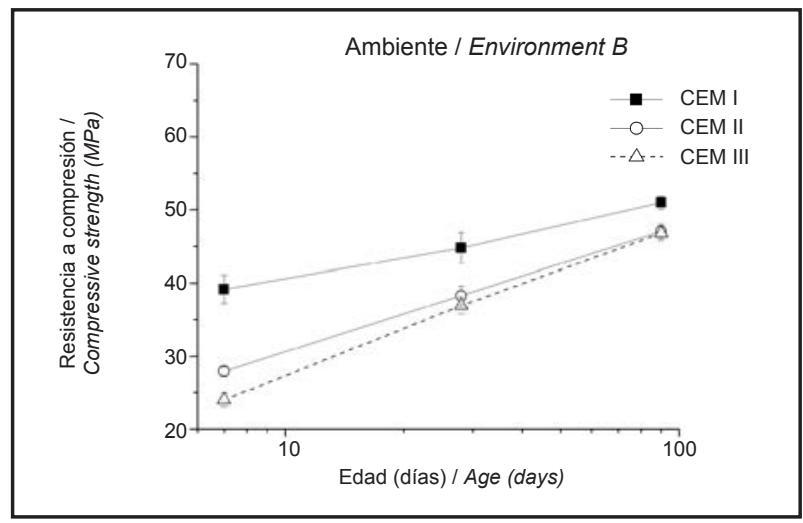

Figura 14. Resultados de resistencia a compresión en las probetas expuestas al ambiente B.

Figure 14. Results of compressive strength for samples exposed to environment $B$. 
Por último, es de interés destacar que al cabo de 90 días, en los ambientes no óptimos las resistencias a compresión de los morteros con adiciones eran inferiores a las obtenidas para el cemento Portland. No obstante, la diferencia de resistencia entre ambos no era excesivamente grande, por lo que resultaría de interés estudiar su evolución a edades superiores, con el fin de comprobar si las resistencias a compresión igualan o superan a las del cemento Portland.
Finally, it is interesting to emphasize that after 90 days, for non-optimum environments the compressive strengths of mortars with additions were lower than those observed for Portland cement. However, the difference of resistance between both types of mortars was not excessively large, therefore it would be interesting to study their evolution at later ages, with the object of proving if the compressive strengths reach similar values or even exceed those observed for Portland cement.



Figura 15. Cambios en la resistencia a compresión que muestran las probetas endurecidas en el ambiente $C$, en función del tipo de cemento.

Figure 15. Compressive strength changes shown by samples hardened under environment $C$, depending on cement type.

\section{CONCLUSIONES}

- Una mayor humedad relativa en el ambiente, en combinación con una temperatura suficientemente elevada, trae consigo el desarrollo de una microestructura más refinada, un incremento de las resistencias mecánicas y una mejora de las propiedades de durabilidad de los morteros con ceniza volante y escoria de alto horno.

- El ambiente representativo del clima Atlántico influye en mayor medida en el desarrollo de la microestructura de los morteros con ceniza volante y escoria de alto horno, que en el de los morteros de cemento Portland.

- En un ambiente representativo del clima Mediterráneo se produce un descenso más tardío de la porosidad total para los tres tipos de cemento estudiados.

- En general, al cabo de 90 días de endurecimiento, los morteros con ceniza volante y escoria de alto horno muestran mejores propiedades de durabilidad que los morteros de cemento Portland, especialmente en lo referente a la resistencia al ingreso de cloruros, en los tres ambientes estudiados.

- En los ambientes no óptimos las resistencias a compresión a 90 días de los morteros con adiciones son inferiores a las obtenidas para el cemento Portland. No obstante, la diferencia de resistencia entre ambos tipos de morteros no es demasiado elevada.

\section{CONCLUSIONS}

- A higher environmental relative humidity, combined with a high enough temperature, produces the development of a more refined microstructure, an increase of mechanical strengths and an improvement of durability properties of mortars with fly ash and blast-furnace slag.

- The environment representative of Atlantic climate has a higher influence on the microstructure development of mortars with fly ash and blast-furnace slag, than on cement Portland mortars.

- In an environment representative of Mediterranean climate, it is produced a late decrease of the mortar total porosity for the three types of cement studied.

- In general, after 90 hardening days, mortars with fly ash and blast-furnace slag show better durability properties than those observed for Portland cement mortars, especially with regard to chloride ingress resistance, for the three environments studied.

- For non-optimum environments, the compressive strengths at 90 days for mortars with additions are lower than those obtained for Portland cement. However, the strength differences between both types of mortars are not excessively large. 
Influencia de diferentes condiciones de curado en la estructura porosa y en las propiedades a edades tempranas de morteros que contienen ceniza... Influence of different curing conditions on the pore structure and the early age properties of mortars with fly ash and blast-furnace slag

- Los resultados obtenidos muestran un buen comportamiento de los morteros con ceniza volante y escoria de alto horno en los tres ambientes estudiados después de 90 días de exposición.

\section{AGRADECIMIENTOS}

Este trabajo ha sido financiado por el Ministerio de Ciencia e Innovación y Economía y Competitividad del Gobierno de España a través de los proyectos BIA2010-20548 y BIA201125721. J.M. Ortega ha sido beneficiario de una beca predoctoral perteneciente al programa de "Formación de Personal Investigador (FPI)" (referencia BES-2008-002650). Los autores quieren agradecer a Holcim España, S.A., a Lafarge España, S.A y a Cementos Portland Valderrivas, S.A. el haber facilitado los cementos estudiados en este trabajo.
- The obtained results show a good behaviour of mortars with fly ash and blast-furnace slag for the three environments studied after 90 days of exposure.

\section{ACKNOWLEDGEMENTS}

This work has been financially supported by the Ministerio de Ciencia e Innovación y Economía y Competitividad of Spanish Government through projects BIA2010-20548 and BIA2011-25721. J.M. Ortega is indebted for a fellowship of the "Formación de Personal Investigador (FPI)" programme (reference BES-2008-002650). Authors would like to thank Holcim España, S.A., Lafarge España, S.A. and Cementos Portland Valderrivas, S.A. for providing the cements studied in this work.

\section{BIBLIOGRAFÍA / BIBLIOGRAPY}

(1) Bijen, J.: "Benefits of slag and fly ash", Constr. Build. Mater., vol. 10, no 5 (1996), pp. 309-314. doi: 10.1016/0950-0618(95)00014-3.

(2) Nochaiya, T., Wongkeo, W., Chaipanich, A.: "Utilization of fly ash and silica fume and properties of Portland cement-fly ash-silica fume concrete", Fuel, vol. 89, no 3 (2010), pp. 768-774. doi: 10.1016/j.fuel.2009.10.003.

(3) Jau, W.C., Tsay, D.S.: "A study of basic engineering properties of slag cement concrete and its resistance to sea water corrosion", Cem. Concr. Res., vol. 28, no 10 (1998), pp. 1363-1371. http://dx.doi.org/10.1016/S0008-8846(98)00117-3

(4) Sánchez, I., López, M.P., Ortega, J.M. and Climent, M.A.: "Impedance spectroscopy: an efficient tool to determine the non-steady-state chloride diffusion coefficient in building materials", Mat. and Corr., vol. 62, no 2 (2011), pp. 139-145. doi: 10.1002/maco.201005775.

(5) Geiseler, J., Kollo, H., Lang, E.: "Influence of blast furnace cements on durability of concrete structures", ACI Mat. J., vol. 92, no 3 (1995), pp. 252-257.

(6) Papadakis, V.G.: "Effects of fly ash on Portland cement system, Part I Low-calcium fly ash", Cem. Concr. Res., vol. 29 , no 11 (1999), pp. 1727-1736. doi: 10.1016/S0008-8846(99)00153-2.

(7) Wang, A., Zhang, C., Sun, W.: "Fly ash effects II. The active effect of fly ash", Cem. Concr. Res., vol. 34, no 11 (2004), pp. $2057-2060$. doi: 10.1016/j.cemconres.2003.03.001.

(8) Manmohan, D., Mehta, P.K.: "Influence of pozzolanic, slag and chemical admixtures on pore size distribution and permeability of hardened cement pastes", Cement, Concrete, and Aggregates, vol. 3, no 3 (1981), pp. 63-67.

(9) Sánchez, I., López, M.P. Climent, M.A.: "Effect of fly ash on chloride transport through concrete: Study by impedance spectroscopy" en: Beaudoin, J.J., Makar, J.M., Raki, L. (eds.): Durability and Degradation of Cement Systems: Corrosion and Chloride Transport; T4.04-4. Proceedings of the 12th International Congress on the Chemistry of Cement, National Research Council of Canada, Montreal, (2007).

(10) Leng, F., Feng, N., Lu, X.: "An experimental study on the properties of resistance to diffusion of chloride ions of fly ash and blast furnace slag concrete", Cem. Concr. Res., vol. 30, no 6 (2000), pp. 989-992. doi: 10.1016/S0008-8846(00)00250-7.

(11) Bouikni, A., Swamy, R.N., Bali, A.: "Durability properties of concrete containing 50\% and 65\% slag", Constr. Build. Mater., vol. 23 , no 8 (2009), pp. 2836-2845. doi: 10.1016/j.conbuildmat.2009.02.040.

(12) Maltais, Y., Marchand, J.: "Influence of curing temperature on cement hydration and mechanical strength development of fly ash mortars", Cem. Concr. Res., vol. 27, no 7 (1997), pp. 1009-1020. http://dx.doi.org/10.1016/S0008-8846(97)00098-7

(13) Schindler, A.K.: "Effect of temperature on hydration of cementitious materials", ACI Mat. J., vol. 101, no 1 (2004), pp. $72-81$.

(14) Escalante-García, J.I., Sharp, J.H.: "The microestructure and mechanical properties of blended cements hydrated at various temperatures", Cem. Concr. Res., vol. 31, no 9 (2001), pp. 695-702. doi: 10.1016/S0008-8846(01)00471-9.

(15) Ramezanianpour A.A., Malhotra, V.M.: "Effect of curing on the compressive strength, resistance to chloride-ion penetration and porosity of concretes incorporating slag, fly ash or silica fume", Cem. Concr. Comp., vol. 17, nº 2 (1995), pp. 125-133. http://dx.doi.org/10.1016/09589465(95)00005-W

(16) Asociación Española de Normalización y Certificación. Cemento. Parte 1: Composición, especificaciones y criterios de conformidad de los cementos comunes. Norma UNE-EN 197-1. Madrid, España, 2000.

(17) Asociación Española de Normalización y Certificación. Métodos de ensayo de cementos. Parte 1: Determinación de resistencias mecánicas. Norma UNE-EN 196-1. Madrid, España, 2005. 
(18) Deutsches Institut für Normung e.V. Standard atmospheres over aqueous solutions (saturated salt solutions, glycerol solutions). Deutsche Norm DIN 50008 Part 1. Berlin, Germany, 1981.

(19) Cabeza, M., Merino, P., Miranda, A., Nóvoa, X.R., Sánchez, I.: "Impedance spectroscopy study of hardened Portland cement paste", Cem. Concr. Res., vol. 32, no 6 (2002), pp. 881-891. doi: 10.1016/S0008-8846(02)00720-2.

(20) Diamond, S.: "Aspects of concrete porosity revisited", Cem. Concr. Res., vol. 29, no 8 (1999), pp. 1181-1188. doi: 10.1016/S00088846(99)00122-2.

(21) Diamond, S.: "Mercury porosimetry. An inappropriate method for the measurement of pore size distributions in cement-based materials", Cem. Concr. Res., vol. 30, no 10 (2000), pp. 1517-1525. doi: 10.1016/S0008-8846(00)00370-7.

(22) Gallé, C.: "Effect of drying on cement-based materials pore structure as identified by mercury intrusion porosimetry. A comparative study between oven, vacuum and freeze-drying", Cem. Concr. Res., vol. 31, no 10 (2001), pp. 1467-1477. doi: 10.1016/S00088846(01)00594-4.

(23) Asociación Española de Normalización y Certificación. Durabilidad del hormigón. Métodos de ensayo. Determinación de la absorción de agua por capilaridad del hormigón endurecido. Método Fagerlund. Norma UNE 83.982, Madrid, España, 2008.

(24) Rilem recommendation TC 116-PCD: "Permeability of Concrete as a Criterion of its Durability", Mater. Struct., vol. 32 , no 217 (1999), pp. 174-179.

(25) Asociación Española de Normalización y Certificación. Durabilidad del hormigón. Acondicionamiento de muestras de hormigón para los ensayos de permeabilidad a gases y capilaridad. Norma UNE 83966. Madrid, España, 2008.

(26) Punkki, J., Sellevold, E.J.: "Capillary suction in concrete: Effects of drying procedure", Nordic Concrete Research Publication, No. 15, 2/94, Oslo, December (1994).

(27) Nordtest. NT Build 492. Concrete, mortar and cement-based repair materials: Chloride migration coefficient from non-steady-state migration experiments. Espoo, Finland, 1999.

(28) ASTM Standard C 1202-97, Standard test method for electrical indication of concrete's ability to resist chloride ion penetration, Annual Book of ASTM Standard Section 4, vol.04.02, 2000.

(29) Chindaprasirt, P., Jaturapitakkul, C., Sinsiri, T.: "Effect of fly ash fineness on compressive strength and pore size of blended cement paste", Cem. Concr. Comp., vol. 27, no 4 (2005), pp. 425-428. doi: 10.1016/j.cemconcomp.2004.07.003.

(30) Schiessl, P., Wiens, U.: "Rapid determination of chloride diffusivity in concrete with blending agents", en: Proceedings of RILEM International Workshop on chloride penetration into concrete, pp. 115-125, (1995).

(31) Ortega, J.M., Sánchez, I., Climent, M.A.: "Influence of environmental conditions on the durability properties of slag cement mortars", en: Zachar, J., Claisse, P., Naik, T.R., Ganjian, E. (eds.): Proceedings of the 2nd International Conference on Sustainable Construction Materials and Technologies, pp. 277-287, UWM Center for By-Products Utilization, Milwaukee, (2010).

(32) Detwiler, J., Kjellsen, K.O., Gjorv, O.E.: "Resistance to chloride intrusion of concrete cured at different temperatures", ACI Mat. J., vol. 88, no 1 (1991), pp. 19-24.

(33) Barnett, S.J., Soutsos, M.N., Millard, S.G., Bungey, J.H.: "Strength development of mortars containing ground granulated blast-furnace slag: Effect of curing temperature and determination of apparent activation energies", Cem. Concr. Res., vol. 36, no 3 (2006), pp. $434-440$. doi: 10.1016/j.cemconres.2005.11.002.

(34) Thomas, M.D.A., Matthews, J.D.: "Performance of Pfa concrete in a marine environment - 10-year results", Cem. Concr. Comp., vol. 26, no 1 (2004), pp. 5-20. doi: 10.1016/S0958-9465(02)00117-8.

(35) Thomas, M.D.A., Scott, A., Bremmer, T., Bilodeau, A., Day, D.: "Performance of slag concrete in marine environment", ACI Mat. J., vol. 105, no 6 (2008), pp. 628-634.

(36) Chalee, W., Ausapanit, P., Jaturapitakkul, C.: "Utilization of fly ash concrete in marine environment for long term design life analysis", Mater. Design, vol. 31, no 3 (2010), pp. 1242-1249. doi: 10.1016/j.matdes.2009.09.024. 